\title{
Molecular Identification of Shiga-Toxin Producing and Enteropathogenic Escherichia coli (STEC and EPEC) in Diarrheic and Healthy Young Alpacas
}

\author{
Lorena Mori ${ }^{1,2 *}$, Rosa Perales ${ }^{1}$, Jorge Rodríguez ${ }^{1,2}$, Carlos Shiva ${ }^{3}$, Ysabel Koga ${ }^{2}$, \\ Geraldine Choquehuanca ${ }^{1}$, Cesar Palacios ${ }^{1}$ \\ ${ }^{1}$ Faculty of Veterinary Medicine, San Marcos National University, Lima, Peru \\ ${ }^{2}$ Bioservice SRL, Lima, Peru \\ ${ }^{3}$ Veterinary and Zootechnic Faculty, Cayetano Heredia University, Lima, Peru \\ Email: ${ }^{\text {Iorena.mori@bioservice.com.pe }}$
}

Received 17 March 2014; revised 18 April 2014; accepted 30 April 2014

Copyright (C) 2014 by authors and Scientific Research Publishing Inc.

This work is licensed under the Creative Commons Attribution International License (CC BY).

http://creativecommons.org/licenses/by/4.0/

(c) (i) Open Access

\begin{abstract}
Isolation and biochemical and molecular identification of 303 strains of Escherichia coli obtained from diarrheic and healthy young alpacas of Puno-Peru, were realized. PCR amplification for 7 virulence factor genes associated with STEC, STEC 0157:H7, EPEC: sxt1, sxt2, rfbO157, fliCH7, hlyA, eae $y$ bfp were determined. A total of 39 strains (12.88\%) showed amplification for one or more of these genes. Twenty three strains (59\%) were classified as STEC and 16 strains (41\%) as EPEC. An 88.18\% (34/39) of STEC and EPEC strains were obtained from healthy alpacas and only $11.82 \%$ $(5 / 39)$ from diarrheic alpacas considering this specie as potential zoonotic reservoir of STEC and EPEC.
\end{abstract}

\section{Keywords}

Shiga Toxin Producing Escherichia coli, Enteropathogenic Escherichia coli, Diarrhea, Young Alpacas

\section{Introduction}

Escherichia coli is a worldwide pathogen causing intestinal and extraintestinal disease in man, children, and

"Corresponding author.

How to cite this paper: Mori, L., et al. (2014) Molecular Identification of Shiga-Toxin Producing and Enteropathogenic Escherichia coli (STEC and EPEC) in Diarrheic and Healthy Young Alpacas. Advances in Microbiology, 4, 360-364. 
animals, especially young animals. Nowadays, there are six pathotypes which cause diarrhea: Shiga toxin producing E. coli (STEC), enteropathogenic E. coli (typical or atypical EPEC), enterotoxigenic E. coli (ETEC), enteroinvasive E. coli (EIEC), diffusely adherent (DAEC), enteroaggregative E. coli (EAEC), from which, enterohemorrhagic E. coli (EHEC), a subtype or subgroup of STEC is associated to two major diseases in humans, the urine-hemolytic syndrome (UHS) and the hemorrhagic colitis (HC), being the serotype O157:H7 its main representative [1]. In Peru, STEC and EPEC are two of the most important E. coli pathotypes that produce diarrheic syndrome in children [2]-[4]. Peru has the greatest alpaca population with approximately four million of alpacas [5], and constitutes an important economic resource to Andean communities with almost 200,000 habitants involved in this production system. However, insufficient information of zoonotic potential of $E$. coli strains from alpacas was generated. The objective of this study was to evaluate the presence of virulence factors, its association with diarrhea [6]-[9], and the evaluation of alpaca as potential reservoirs of E. coli zoonotic pathotypes.

\section{Materials and Methods}

\subsection{Animals and Samples}

The samples were collected from Andean communities in the department of Puno during January to March of 2007 (mating-breeding season). Three hundred twenty four samples of rectal and anal mucosal swab were collected from young alpacas up to 60 days old. The samples were divided in two paired groups (age, sex and origin): 1) clinical diarrhea $(\mathrm{N}=162)$; and 2) without diarrhea $(\mathrm{N}=162)$. Samples were placed in Cary-Blair transport medium and stored at $8^{\circ} \mathrm{C}$ until their processing.

\subsection{Biochemical and Virulence Factors Identification}

Samples were cultured in McConkey agar and incubated at $37^{\circ} \mathrm{C}$ for 18 to 24 hours. Evaluation of bacterial colonies and biochemistry were realized, strains that showed compatible results with $E$. coli were selected [8]. Molecular confirmation was performed using a simple PCR for universal stress protein (uspA) [10]. Genomic DNA was extracted using Promega Wizard Genomic ADN Isolation kit (PROMEGA) according to manufacturer. PCR for 7 virulence factor genes: Shiga toxin 1 (stx1A) [11], Shiga toxin 2 (stx2A) [11], Intimin (eaeA) [12], Bundle forming pilus (bfp) [13], Flagelar antigen H7 (fliCH7) [14], Somatic antigen O157 (rfbO157) [15], Enterohemolysin (hlyA) [16] were performed. In brief, the PCR reaction was realized using a final volume of 20 uL containing $10 \mathrm{ng}$ genomic DNA, 1X PCR buffer (20 mM Tris-HCl, $\left.20 \mathrm{mM} \mathrm{KCl,} 5 \mathrm{mM}\left(\mathrm{NH}_{4}\right)_{2} \mathrm{SO}_{4}\right), 2 \mathrm{mM}$ $\mathrm{MgCl}_{2}$, between 0.75 to 4 pmol of each primer (Table 1), $0.2 \mathrm{mM}$ of dNTPs, $0.5 \mathrm{U}$ Maxima HotStart-Taq DNA

Table 1. Target gene, primer sequences, primer concentration and PCR product size.

\begin{tabular}{|c|c|c|c|c|}
\hline Target gene & Primer & Sequence 5'-3' & $\begin{array}{c}\text { Concentration } \\
\text { (pmol) }\end{array}$ & $\begin{array}{l}\text { PCR product } \\
\text { size (bp) }\end{array}$ \\
\hline \multirow{2}{*}{ Shiga toxin $1(s t x 1 A)$} & LP30 & CAGTTAATGTCGTGGCGAAGG & \multirow{2}{*}{1.4} & \multirow[t]{2}{*}{348} \\
\hline & LP31 & CACCAGACAATGTAACCGCTG & & \\
\hline \multirow{2}{*}{ Shiga toxin $2(s t x 2 A)$} & LP43 & ATCCTATTCCCGGGAGTTTACG & \multirow{2}{*}{1} & \multirow[t]{2}{*}{584} \\
\hline & LP44 & GCGTCATCGTATACACAGGAGC & & \\
\hline \multirow{2}{*}{ Intimin $(e a e A)$} & Int-Fc & CCGGAATTCGGGATCGATTACCGTCAT & \multirow{2}{*}{2} & \multirow[t]{2}{*}{840} \\
\hline & Int-Rc & CCCAAGCTTTTATTTATCAGCСTTAATCTC & & \\
\hline \multirow{2}{*}{ Bundle forming pilus ( $b f p$ ) } & Bfp-F & GGAAGTCAAATTCATGGGGGTAT & \multirow{2}{*}{1.5} & \multirow[t]{2}{*}{254} \\
\hline & Bfp-R & GGAATCAGACGCAGACTGGTAGT & & \\
\hline \multirow{2}{*}{ Flagelar antigen $\mathrm{H} 7(\mathrm{fliCH} 7)$} & FLICH7-F & GCGCTGTCGAGTTCTATCGAGC & \multirow{2}{*}{2} & 625 \\
\hline & FLICH7-R & CAACGGTGACTTTATCGCCATTCC & & \\
\hline \multirow{2}{*}{ Somátic antigen O157 (rfbO157) } & PF8 & CGTGATGATGTTGAGTTG & \multirow{2}{*}{0.75} & \multirow[t]{2}{*}{420} \\
\hline & PR8 & AGATTGGTTGGCATTACTG & & \\
\hline \multirow{2}{*}{ Enterohemolysin (hlyA) } & hlyA-F & GCATCATCAAGCGTACGTTCC & \multirow[b]{2}{*}{4} & \multirow[t]{2}{*}{534} \\
\hline & hlyA-R & AATGAGCCAAGCTGGTTAAGCT & & \\
\hline
\end{tabular}


polymerase (Fermentas). Thermal cycles were the following: initial denaturation of $94^{\circ} \mathrm{C}$ for 3 minutes, 30 cycles of $94^{\circ} \mathrm{C}$ for 30 seconds, $53^{\circ} \mathrm{C}$ for 60 seconds, $72^{\circ} \mathrm{C}$ for 30 seconds and a final extension of $72^{\circ} \mathrm{C}$ for $5 \mathrm{mi}-$ nutes. The PCR amplification was carried out using a Veriti Thermal cycler (Applied Biosystems). The PCR products were separated in $2 \%$ agarose gel TBE $1 \mathrm{X}$ electrophoresis and visualized by fluorescence using an ethidium bromide solution $(0.1 \mathrm{ug} / \mathrm{mL})$ and UV light using a BioDoc-It system.

\section{Results and Discussion}

A total of 39 isolates (12.88\%) showed amplification for one or more virulence factor genes: Shiga toxin 1 (stx1A), Shiga toxin 2 (stx2A), Intimin (eaeA), Flagelar antigen H7 (fliCH7) and Enterohemolysin (hlyA) (Figure 1), constituted 11 E. coli toxinotypes, 1 in EPEC and 10 at STEC. A total of 23 strains of E. coli (59\%) were identified as STEC and 16 (41\%) as atypical EPEC (EPECa) due to absence of the bfpA gene (Table 2). A $2.1 \%$ of E. coli strains (3/149) isolated from alpacas with diarrhea was identified as STEC, and $1.3 \%(2 / 149)$ as EPECa in contrast with 12.9\% (20/154) for STEC and 9.1\% (14/154) for EPECa from alpacas without diarrhea (Table 2).

Previous studies in alpacas from Peru [6] [8] [9] reported a STEC as the predominant pathotype in samples of young alpacas with diarrhea. Also, a study in guanaco with diarrhea from Argentina reported the presence of STEC [17]. However, the presence of STEC and EPECa strains in higher proportion in alpacas without diarrhea in comparison to alpacas with diarrhea contrasts with previous reports [7]. Of all strains of STEC detected in alpacas without diarrhea, sxt2A gene as a single gene or in combination with stx1A, eaeA and hlyA genes was most frequent gene (11/20), similar to reported by other authors [8] [18] in contrast to reported in cattle from Lima (year 2010) where the stx1 gene was most frequent [19].

The EPECa is among the most important pathogens causing acute and persistent diarrhea in children in Peru [2] [3]. Studies in cattle, sheep and pigs also showed that these animal species may be a source of strains EPECa and STEC [19] [20]. Therefore, the detection of 14 strains of EPECa in alpacas without diarrhea in this study showed preliminary evidence that alpacas can be EPECa reservoir. Additionally, the presence of STEC strain with the stx2 gene, alone or in combination with eae, could be associated with the development of UHS and HC

Table 2. Detected genes by multiplex PCR in E. coli strains isolated from feces of 303 young alpacas.

\begin{tabular}{|c|c|c|c|}
\hline \multirow{2}{*}{ E. coli genotypes (Detected genes) } & \multicolumn{3}{|c|}{ E. coli strains isolated } \\
\hline & With diarrhea N (\%) & Without diarrhea N (\%) & Total N (\%) \\
\hline \multicolumn{4}{|l|}{ EPEC } \\
\hline eae & $2(1.3)$ & $14(9.1)$ & $16(5.3)$ \\
\hline \multicolumn{4}{|l|}{ STEC } \\
\hline sxt1 & $1(0.7)$ & $2(1.3)$ & $3(1.0)$ \\
\hline sxt2 & $1(0.7)$ & $7(4.6)$ & $8(2.6)$ \\
\hline$s x t 1+s x t 2$ & 0 & $1(0.6)$ & $1(0.3)$ \\
\hline sxt $1+e a e$ & 0 & $2(1.3)$ & $2(0.7)$ \\
\hline sxt2+eae & 0 & $1(0.6)$ & $1(0.3)$ \\
\hline sxt2+hlyA & $1(0.7)$ & $1(0.6)$ & $2(0.7)$ \\
\hline sxt1+hlyA & 0 & $2(1.3)$ & $2(0.7)$ \\
\hline sxt $1+e a e+h l y A$ & 0 & $2(1.3)$ & $2(0.7)$ \\
\hline$s x t 2+e a e+h l y A$ & 0 & $1(0.6)$ & $1(0.3)$ \\
\hline sxt1 +hlyA+fliCH7 & 0 & $1(0.6)$ & $1(0.3)$ \\
\hline None & $144(96.6)$ & $120(78)$ & $264(87)$ \\
\hline Total & $149(100)$ & $154(100)$ & $303(100)$ \\
\hline
\end{tabular}




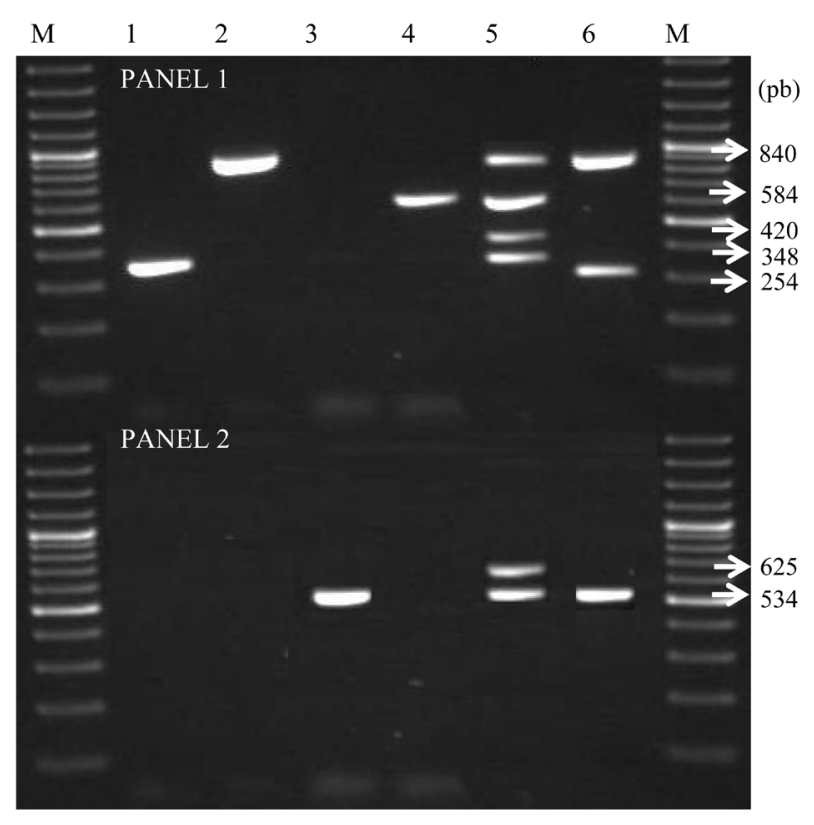

Figure 1. Panel 1: Line 1, stx1A positive sample, line 2, eaeA positive sample, line 3 , ETEC H10407, line 4, sxt2 positive sample; line 5, EHEC O157: H7 (eaeA, stx2A, rfbO157 and stx1A positive), line 6, EPEC 2348/69 (eaeA and bfpA positive) and line $\mathrm{M}$, molecular marker of $100 \mathrm{pb}$. Panel 2: Line 1 and 2 negative samples, line 3, hlyA positive sample, line 4, ETEC H10407; line 5, EHEC O157: H7 (fliCH7 and hlyA positive), line 6, STEC 3153-86 (hlyA positive).

in humans [1]. The presence of theses virulence factors in healthy alpacas and the breeding management in Peru allows close contact between animals and humans, increasing the risk of transmission, primarily through contamination of food or water with alpaca feces.

\section{Acknowledgements}

The authors sincerely thank the International Foundation for Science (IFS) for the financial support as well as Dr. Sonia Calle Espinoza (Laboratory of Microbiology and Parasitology, San Marcos National University) and Dr. Teresa Ochoa (Institute of Tropical Medicine Alexander von Humboldt, Cayetano Heredia University), who made the development of this work possible.

\section{References}

[1] Nataro, J and Kaper, J. (1998) Diarrheagenic Escherichia coli. Clinical Microbiology Reviews, 11, $142-201$. http://cmr.asm.org/content/11/1/142.full.pdf+html

[2] Arias, I., Caceres, O., Salazar, L., Zamudio, M.L. and Huguet, J.C. (2000) Estudio de Escherichiacolienteropatógena y enteroagregativa en menores de cinco años de edad con diarrea persistente. http://www.bvs.ins.gob.pe/insprint/cindoc/informes_tecnicos/34.pdf

[3] Ochoa, T.J., Contreras, C. and Mosquito, S. (2010)Alcances sobre la situación epidemiológica de las E. Coli diarreogénicas aisladas de niños peruanos. Canarias Pediátrica, 34, 133-138. http://www.scptfe.com/inic/download.php?idfichero=534

[4] Ochoa, T.J., Mercado, E., Durand, D., Rivera, F., Mosquito, S., Contreras, C., et al. (2011) Frecuencia y patotipos de Escherichia coli diarrogénica en niños peruanos con y sin diarrea. Revista Peruana de Medicina Experimental y Salud Pública, 28, 13-20. http://dx.doi.org/10.1590/S1726-46342011000100003

[5] Rosadio, R., Maturrano, L., Pérez, D. and Luna, L. (2012) El complejo entérico young en alpacas andinas. Revista de Investigaciones Veterinarias del Perú, 23, 621-271.

[6] Bravo de Rueda, C. (2006) Caracterización molecular de los genes sxt1, sxt2 y eae de E. coli aisladas de alpacas 
neonatas con diarrea. Grade Thesis, Cayetano Heredia University, Lima.

[7] Luna, L. (2009) Genotipificación de cepas de Escherichiacoli aislados de crías de alpacas con diarrea. Grade Thesis, San Marcos National University, Lima.

[8] Silvera, E.D. (2009) Presencia de Escherichia coli O157 en crías de alpacas (Vicugna pacos). Grade Thesis, San Marcos NationalUniversity, Lima.

[9] Cid, D., Martín-Espada, C., Maturrano, L., García, A., Luna, L. and Rosadio, R. (2012) Diarrheagenic Escherichia coli strains isolated from young Peruvian alpacas (Vicugnapacos) with diarrea. En: Perez-Cabal, M.A., et al., Eds., Fibre Production in South American Camelids and Other Fibre Animals, 223-228.

[10] Chen, J. and Griffiths, M.W. (1998) PCR differentiation of Escherichia coli from other Gramnegative bacteria using primers derived from the nucleotide sequences flanking the gene encoding the universal stress protein. Letters in Applied Microbiology, 27, 369-371. http://dx.doi.org/10.1046/j.1472-765X.1998.00445.X

[11] Cebula, T,A., Payne, W.L. and Feng, P. (1995) Simultaneous identification of strains of Escherichia coli serotype O157:H7 and their shiga-like toxin type by Mismatch Amplification Mutation Assay-Multiplex PCR. Journal of Clinical Microbiology, 33, 248-250. http://www.ncbi.nlm.nih.gov/pmc/articles/PMC227922/pdf/330248.pdf

[12] Batchelor, M., Knutton, S., Caprioli, A., Huter, V., Zanial, M., Dougan, G., et al. (1999) Development of a universal intimin antiserum and PCR primers. Journal of Clinical Microbiology, 37, 3822-3827. http://jcm.asm.org/content/37/12/3822.long

[13] Vidal, R., Vidal, M., Lagos, R., Levine, M. and Prado, V. (2004) Multiplex PCR for diagnosis of enteric infections associated with diarrheagenic Escherichia coli. Journal of Clinical Microbiology, 42, 1787-1789.

http://jcm.asm.org/content/42/4/1787.full.pdf+html http://dx.doi.org/10.1128/JCM.42.4.1787-1789.2004

[14] Gannon, V.P., D’Souza, S., Graham, T., King, R.K., Rahn, K. and Read, S. (1997) Use of the flagellar H7 gene as a target in multiplex PCR assays and improved specificity in identification of enterohemorrhagic Escherichia coli strains. Journal of Clinical Microbiology, 35, 656-662. http://www.ncbi.nlm.nih.gov/pmc/articles/PMC229645/pdf/350656.pdf

[15] Maurer, J.J., Schmidt, D., Petrosko, P., Sanchez, S., Bolton, L. and Lee, M.D. (1999) Development of primers to O-antigen biosynthesis genes for specific detection of Escherichia coli O157 by PCR. Applied and Environmental Microbiology, 65, 2954-2960. http://www.ncbi.nlm.nih.gov/pmc/articles/PMC91442/pdf/am002954.pdf

[16] Paton, A. and Paton, J. (1998) Detection and characterization of shiga toxigenic Escherichia coli by using multiplex PCR assays for stx1, stx2, eaeA, enterohemorrhagicE. coli hlyA, rfbO111, and rfbO157. Journal of Clinical Microbiology, 36, 598-602. http://jcm.asm.org/content/36/2/598.long

[17] Mercado, E.C., Rodríguez S.M., Elizondo, A.M., Marcoppido, G. and Parreño, V. (2004) Isolation of shiga toxin-producing Escherichia coli from a South American camelid (Lama guanicoe) with diarrhea. Journal of Clinical Microbiology, 42, 4809-4811. http://dx.doi.org/10.1128/JCM.42.10.4809-4811.2004 http://jcm.asm.org/content/42/10/4809.full.pdf+html

[18] Featherstonee, C.A., Foster, A.P. and Chappell, S.A. (2011) Verocytotoxigenic Escherichia coli O157 in camelids. Veterinary Record, 168,194-195. http://dx.doi.org/10.1136/vr.d902

[19] Rivera, F., Sotelo, E., Morales, I., Menacho, F., Medina, A.M., Evaristo, R., et al. (2012) Short communication: Detection of Shiga toxin-producing Escherichia coli (STEC) in healthy cattle and pigs in Lima. Peru. Journal of Dairy Science, 95, 1166-1169. http://www.journalofdairyscience.org/article/S0022-0302(12)00075-6/fulltext http://dx.doi.org/10.3168/jds.2011-4662

[20] Fröhlicher, E., Krause, G., Zweifel, C., Beutin, L. and Stephan, R. (2008) Characterization of attaching and effacing Escherichia coli (AEEC) isolated from pigs and sheep. BMC Microbiology, 8,144. http://dx.doi.org/10.1186/1471-2180-8-144 